\title{
Variations on Maternal-Embryonic Relationship in Two Natural and Six Laboratory Made Hybrids of Poeciliopsis monacha-lucida (Pisces, Cyprinodontiformes)
}

\author{
Neuza Rejane Wille Lima* \\ Universidade Federal Fluminense; Instituto de Biologia; Departamento de Biologia Geral; C.P. 100.436; \\ rejane@nitnet.com.br; 24.001-970; Niterói - RJ - Brazil
}

\begin{abstract}
The objective of this study was to analyze the maternal-embryonic relationship in eight hybrids Poeciliopsis monacha-lucida. Two natural hybrids (MLVII and MLVIII) collected in Mexico, and in a repertory of six hybrids produced by artificial insemination (A1, A4, B1, B2, E1, and E2) were analyzed. Dry weight of mature eggs and of embryos was significantly different among hybrids. All hybrids but B1 and E2 exhibited superfetation and lecithotrophy. This result showed that the association between superfetation and lecithotrophy were not restricted to P. monacha.
\end{abstract}

Key words: Poeciliopsis, hybrids, viviparous, lecithotroph, matrotrophy, superfetation

\section{INTRODUCTION}

Poeciliopsis is a viviparous fish that stores sperm from multiple inseminations in the folds lining the ovary and gonoduct and has two or three broods at different stages of development within their ovaries (superfetation) (Turner, 1937; Thibault and Schultz, 1978). Where high taxonomic diversity is found (e.g. western Mexico), interspecific hybridization leads to the formation of all-female biotypes. These biotypes depend on the sperm of paternal species to reproduce (Schultz, 1969; Schultz, 1989). Such sexual parasitism implies a strong competition for space, food, and sperm among members of mixed reproductive complexes (Vrijenhoek et al., 1989; Schenck and Vrijenhoek, 1989; Weeks et al., 1993; Lima et al., 1996; Lima and Vrijenhoek, 1996; Weeks, 1996; Lima, 1998; Lima and Bizerril, 2002).
The coexistence among all-female biotypes and the sexual ancestors species seems to be paradoxical because the sexual parasite cannot escape or completely replace their host. However these reproductive complexes seem to be temporally stable where sexual species and several all-female biotypes that often successfully co-exist even though strong competition for resources (Stenseth et al., 1985; Vrijenhoek et al., 1989; Weeks et al., 1993; Lima et al., 1996; Lima and Bizerril, 2002).

Reproduction of fishes in the genus Poeciliopsis have been intensively studied to understand how the paradoxical coexistence between sexual and all-female biotypes is possible to identify mechanisms that might sustain a diversity of allfemales (Schultz, 1982; Schultz, 1989; Vrijenhoek, 1984; Vrijenhoek, 1993; Lima et al., 1996; Lima and Bizerril, 2002). The laboratory

\footnotetext{
* Author for correspondence
} 
made hybrids produced by Wetherington et al. (1987) represent new and unselected strains that have been used to analyze several traits to test model that attempt to explain the source and the mechanisms responsible for the hybrid diversities observed in Mexico.

Natural and laboratory made hybrids exhibit variation in life-history, morphology, and behavioral traits (Wetherington et al., 1987; Wetherington et al., 1989; Weeks et al., 1993; Lima et al., 1996; Lima and Vrijenhoek, 1996; Lima, 1998). However the reproductive strategies of these hybrids remain to analyze.

Females of Poeciliopsis exhibit two reproductive modes: lecithotrophy or matrotrophy (Thibault and Schultz, 1978). Lecithotrophic involves loss of 25 to $40 \%$ of dry mass of fertilized eggs during development.

Matrotrophy shows a constant or slight increase of fertilized eggs during embryogenese (Reznick and Miles, 1989). There is a relationship between superfatation and maternal-embryonic relationships. Poeciliopsis lucida exhibits superfatation and are exclusively matrotrophic like other eight species of Poeciliidae. However these two reproductive modes are not strictly linked in Poeciliopsis species.

For example, P. monacha exhibit lecithotrophy and superfatation, carring broods of two different stages of development, representing the only case already described. Although if females of this species live in an unpredictable environment they produce only one brood when food supply is reduced (Thibault and Schultz, 1978).

Thus the analyses variation on reproductive modes in P. monacha-lucida hybrids will permit to ask whether the differences exhibit by the two sexual ancestors are perpetuate after hybridization.
Therefore, the objective of the study was to analyze the maternal-embryonic relationship in two natural hybrids and six laboratory made hybrids resulting from the insemination of $P$. monacha females by $P$. lucida males.

\section{MATERIAL AND METHODS}

Reproduction in the species $P$. monacha and $P$. lucida is biparental and involves conventional Mendelian processes (Leslie, 1982). Two different reproductive modes arose as $P$. monacha $\mathrm{x} P$. lucida hybrids - hybridogenesis and gynogenesis (Schultz, 1967; Schultz, 1969; Cimino, 1972a; Cimino, 1972b). Only hybridogenetic all-female biotypes were analyzed in the present study. Hydridogenesis is an asexual mode restricted to diploid all-females like several biotypes of $P$. monacha-lucida (Schultz, 1967). They produce haploid ova containing only $P$. monacha chromosomes but they rely on P. lucida males for insemination to return to diploid stage (Cimino, 1972b; Schultz, 1989). Two natural hybrids and six laboratory made hybrids of $P$. monacha-lucida were analyzed (Table 1).

The two natural hybrids $P$. monacha-lucida stocks were collected from Jaguary tributary of the Río Fuerte, near the town Agua Caliente, Sonora, northwestern Mexico, in 1968 (MLVII) and 1970 (MLVIII).

The six laboratory made hybrids were maintained by artificial insemination with sperm from a highly inbred P. lucida (LLi) population (strain S68-4) collected from the Jaguary tributary in 1964 (Vrijenhoek, 1978).

Table 1 - List of the Poeciliopsis strains analyzed for the maternal-fetal trophic relationship and their respectively laboratory code and the code adopted by the present study of the natural hybrids ${ }^{(1)}$ and laboratory made hybrids ${ }^{(2)}$.

\begin{tabular}{|c|c|c|}
\hline Strain & Lab code & Code $^{a}$ \\
\hline \multirow[t]{2}{*}{ P. monacha-lucida ${ }^{(1)}$} & S68-4 ML VII & $M L \mathrm{VII}$ \\
\hline & T70-3 ML/VIII & $M L V I I I$ \\
\hline \multirow[t]{6}{*}{ P. monacha-lucida ${ }^{(2)}$} & $\mathrm{AC} 11 / \mathrm{F}$ & A1 \\
\hline & $\mathrm{AC} 11 / \mathrm{L}$ & $\mathrm{A} 2$ \\
\hline & $\mathrm{AC} 10 / \mathrm{O}$ & B1 \\
\hline & $\mathrm{AC} 10 / \mathrm{N}$ & B2 \\
\hline & MY54/EE & E1 \\
\hline & MY53/T & E2 \\
\hline
\end{tabular}

(Source: ${ }^{2}$ Lima, 1998) 
Artificial hybridization was used to produce new all-females of $P$. monacha-lucida (Wetherington et al., 1987). These laboratory made hybrids derived from four wild $P$. monacha females ('foundresses'). Foundresses A and B were collected from the Jaguary tributary. Foundresses $\mathrm{C}$ and $\mathrm{E}$ were collected from the Río Mayo, near the village of El Tabelo, Sonora, northwestern Mexico. These foundresses were artificially inseminated with sperm from $(L L \mathrm{i})$. Upon hybridization, each of four $P$. monacha $(M M)$ foundresses $(\mathrm{A}, \mathrm{B}$, and $\mathrm{E})$ produced sibling hybrids that derived from independent sexually produced eggs [e.g. $M M(\mathrm{~A}) \times L L \mathrm{i}=M(\mathrm{~A} 1) L i$ and $M(\mathrm{~A} 4) L i]$. Thus, $M(\mathrm{~A} 1) L i$ and $M(\mathrm{~A} 4) L i$ were siblings hybrids derived from the foundresse A. For simplicity, the six laboratory made hybrids were refered as A1-E2 (Table 1).

The experimental design followed Wetherington et al. (1987) procedures. To overcome behavioral isolating mechanisms and to insure fertilization twenty females of all hybrids strains (from $29 \mathrm{~mm}$ to $41 \mathrm{~mm}$ of standard lengths) were artificially inseminated with sperm form $(L L \mathrm{i})$. Thus, the hybrids were stabilized by crossed with the isogenic $P$. lucida genome.

Following insemination each female was individually transfered into plastic container (4 liter, $14 \mathrm{~cm}$ deep) suspended in a 1,600 liter, filtered, circulating water bath $\left(28^{\circ} \mathrm{C}, 16 \mathrm{~L}\right.$ : $8 \mathrm{D}$ photo period) (Lima, 1998). Females were fed daily with $1 \mathrm{ml}$ of a suspension of defrosted brine shrimp (Artemia salina) and $0.5 \mathrm{~g}$ of commercial food (Tetra SML) (Lima and Vrijenhoek, 1996).

Gestation of Poeciliopsis took approximately 30 days at $28^{\circ} \mathrm{C}$ (Lima and Vrijenhoek, 1996). Females were eutanized from 15 to 29 days after insemination in iced solution, fixed in formalin $4 \%$ solution and preserved in 70\% solution of alcohol. Ovarian contents of females were analyzed. Eggs bigger then $1.5 \mathrm{~mm}$ diameter and presenting yellow and opac colour were classify as mature (Quattro and Weeks, 1991; Lima and Bizerril, 2002). Embryos were classified for three stage of development considering morphological stages of variation (Turner, 1937; Thibault and Schultz, 1978). The size and weight of Poeciliopsis eggs predicted their energy content (Constantz, 1980; Quattro and Weeks, 1991). Species of fishes can be classified as lecithotrophic or matrotrophic based on weight changes during development (Reznik and Miles, 1989). Thus, the dry weight $\left(50^{\circ} \mathrm{C}, 48 \mathrm{~h}, 0.1 \mathrm{mg}\right.$ precision) of mature eggs and the embryos for the stages of development was quantified to assess variance in reproductive investment among hybrids of $P$. monacha-lucida.

All analyses were performed using the General Linear Models procedures of Statistic (1984). Results of eggs and embryos dry weights were natural-log transformed and data did not significantly deviate from a normal distribution. Analyses of variance (ANOVA, $F$, type III) of eggs and embryos dry weights were performed using strains as covariate.

\section{RESULTS}

Maternal-embryonic relationship was analyzed considering the difference between dry weight of mature eggs and embryos at advance stage of development (Table 2). Dry weight of eggs varied from 1.16mg (strain B1) and $1.52 \mathrm{mg}$ (strain E1).

Variations were also observed for means of dry weight of embryos at initial, intermediated and advanced development (codified as embryo 1, 2, and 3). The strains MLVIII, A4, and B2 presented an increased of dry weight of embryos at initial stage of development but a decreased the follow stages (embryos 2 and 3) were observed. The dry weight of embryos at stage 3 varied from $1.04 \mathrm{mg}$ (MLVII) to $1.80 \mathrm{mg}(\mathrm{E} 2)$.

The two natural hybrids and four of six laboratory made hybrids of $P$. monacha-lucida showed a slight decrease of fertilized eggs dry weight during embryogenese (Table 2). The differences between dry weight (DDW) of eggs and of embryos at stage 3 of these hybrids varied from $-25.9 \%$ (A1) to $-6.9 \%$ (B2). Thus, MLVII, MLVIII, A1, A4, presented lecithotrophy like their maternal ancestor species, $P$. monacha. Only the laboratory made hybrids B1 and E2 presented an increase of $28.8 \%$ and $27 \%$ on the embryos at stage 3, respectively. These two hybrids adopted matrotrophy like females of their paternal ancestor specie, $P$. lucida.

The relationship between standard lengths and number or dry weight of eggs and embryos were not significant $(P>0.05)$. Thus, the analyses of variance (ANOVA) of dry weight of eggs and embryos were performed using strains as covariates (Table 3). The overall analysis of variance showed that means dry weight of eggs and embryos significantly varied among the eight 
hybrid strains $(P=0.005)$. The partition analysis of variance comparing only the six laboratory made hybrids showed significant differences among them $(P=0.003)$.

The analyses of variance between the two natural hybrids (MLVII versus MLVIII) and between the sibling laboratory made hybrids (B1 versus B2; E1 versus E2) showed that they were significantly different for the maternal-embryonic relationship $(P \leq 0.05)$.
The comparison between the strains A1 and A4 reveled that they were not significantly different $(P=0.01)$. The variation of dry weight along the embryonic development was significant $(P=0.045)$ only for the strain E2. The variance of results for the other strains was not significant $(P>0.05)$.

Table 2 - Mean and standard deviation of dry weight $(\mathrm{mg})$ of ovarian content obtained from hybrid strains of Poeciliopsis listed in table 1. The ovarian content was classified in four stages: egg, initial (embryo 1), intermediate (embryo 2), and advanced development (embryo 3). The differences between dry weight (DDW) of eggs and of embryos at stage 3 were expressed by percentage (\%).

\begin{tabular}{|c|c|c|c|c|c|c|}
\hline \multirow[b]{2}{*}{ Strain } & \multirow[b]{2}{*}{ (n) } & \multicolumn{4}{|c|}{ Stages } & \multirow[b]{2}{*}{ DDW (\%) } \\
\hline & & Egg & Embryo 1 & Embryo 2 & Embryo 3 & \\
\hline$M L \mathrm{VII}$ & (18) & 1.45 & 1.36 & 1.18 & 1.19 & -17.9 \\
\hline$M L \mathrm{VIII}$ & (13) & $\begin{array}{c}(0.23) \\
1.27\end{array}$ & $\begin{array}{c}(0,24) \\
1.65\end{array}$ & $\begin{array}{c}(0,09) \\
1.27\end{array}$ & $\begin{array}{c}(0.37) \\
1.04\end{array}$ & $-18,1$ \\
\hline & & $(0.16)$ & $(0.55)$ & $(0.05)$ & $(0.06)$ & \\
\hline A1 & (17) & 1.81 & 1.54 & 1.53 & $\begin{array}{c}1.34 \\
(0.04)\end{array}$ & -25.9 \\
\hline A4 & (18) & $\begin{array}{c}1.51 \\
(0.23)\end{array}$ & $\begin{array}{c}1.68 \\
(0.31)\end{array}$ & $\begin{array}{c}1.36 \\
(0.32)\end{array}$ & $\begin{array}{c}1.26 \\
(0.33)\end{array}$ & -16.6 \\
\hline B1 & (13) & $\begin{array}{c}1.16 \\
(0.12)\end{array}$ & $\begin{array}{c}1.38 \\
(0.10)\end{array}$ & $\begin{array}{c}1.67 \\
(0.05)\end{array}$ & $\begin{array}{c}1.63 \\
(0.04)\end{array}$ & +28.8 \\
\hline B2 & (17) & $\begin{array}{c}1.17 \\
(0.21)\end{array}$ & $\begin{array}{c}1.25 \\
(0.08)\end{array}$ & $\begin{array}{c}1.18 \\
(0.13)\end{array}$ & $\begin{array}{c}1.09 \\
(0.17)\end{array}$ & -6.9 \\
\hline E1 & (18) & $\begin{array}{c}1.52 \\
(0.23)\end{array}$ & $\begin{array}{c}1.43 \\
(0.38)\end{array}$ & $\begin{array}{c}1.31 \\
(0.41)\end{array}$ & $\begin{array}{c}1.17 \\
(0.09)\end{array}$ & -23.0 \\
\hline E2 & (16) & $\begin{array}{c}1.31 \\
(0.41)\end{array}$ & $\begin{array}{c}1.69 \\
(0.05)\end{array}$ & $\begin{array}{c}1.71 \\
(0.40)\end{array}$ & $\begin{array}{c}1.80 \\
(0.30)\end{array}$ & +27.0 \\
\hline
\end{tabular}

Table 3 - ANOVA ( $F$, type III) for dry weight of eggs and embryos of the two natural hybrids (MLVII and MLVIII) and six laboratory made hybrids of Poeciliopsis monacha-lucida.

\begin{tabular}{cclr}
\hline Analysis & d.f. & $\boldsymbol{F}$ & \multicolumn{1}{c}{$\boldsymbol{P}$} \\
\hline Among all hybrids & 3.13 & 2.463 & $0.005^{*}$ \\
Among six laboratory made hybrids & 3.98 & 2.619 & $0.003^{*}$ \\
MLVII x MLVIII & 3.30 & 3.432 & $0.021^{*}$ \\
A1 x A4 & 3.34 & 1.901 & 0.100 \\
B1 x B2 & 3.29 & 2.889 & $0.037^{*}$ \\
E1 x E2 & 3.33 & 2.677 & $0.026^{*}$ \\
MLVII & 3.17 & 0.770 & 0.533 \\
MLVIII & 3.12 & 0.304 & 0.821 \\
A1 & 3.16 & 1.606 & 0.229 \\
A4 & 3.17 & 1.882 & 0.117 \\
B1 & 3.12 & 1.175 & 0.307 \\
B2 & 3.16 & 0.471 & 0.709 \\
E1 & 3.17 & 3.025 & 0.086 \\
E2 & 3.15 & 4.861 & $0.045^{*}$ \\
\hline
\end{tabular}

$(* P \leq 0.05)$ 


\section{DISCUSSION}

Viviparity is wide spread in all major groups of fishes and is the dominant mode of reproduction in $50 \%$ of chondrichthyan species but is rare among bone fishes (3\% of species distributed in 15 families). Besides, the ovarians of bone fishes house both eggs production and embryos development (superfetation), representing a particular situation among vertebrates (Wourms, 1988).

The present study is the first evidence that natural hybrids of $P$. monacha-lucida strain MLVII and MLVIII heredity monacha reproductive strategy, showing superfetation and no maternal investment in embryonic growth (lecithotrophy). Therefore, the $P$. monacha reproductive strategy is not an exception in nature.

Among the laboratory made hybrids, the strains A1, A4, B2, and E1 also showed monacha-like pattern. However the laboratory made hybrids B1 and E2 presented superfatation and matrothophy. Therefore, the lucida-like tendency appears to be particularly dominant in these two strains.

Variances in the degree of dominance of monacha gene expression were observed in the present study. The same pattern had been observed for MLVII and MLVIII and in the most of the laboratory made hybrids for life-history traits, genital pigmentation, maternal cannibalism, innate avoidance of filial cannibalism, aggressiveness, and feeding behavior (Wetherington et al., 1989; Weeks et al., 1993; Lima et al., 1996; Lima and Vrijenhoek, 1996; Lima, 1998).

The present results suggested that the unusual reproductive mode of $P$. monacha expressed by the strains $M L V I I$ and MLVIII cannot be evolved subsequent to their origins as hybrids because of similar patterns were observed among most of the unselected laboratory made hybrids. These results corroborated to the two premises (known as 'frozen niche-variation model') that attempt to explain how the phenotypic variation on allfemales $P$. monacha-lucia arouse and how it is necessary to the coexistence among hybrids as well as between them and their sexual relatives (P. monacha and P. lucida) (Vrijenhoek, 1979; Vrijenhoek, 1984).

According to frozen niche-variation model, differences among natural hybrids are frozen from genomic variation that exists in the sexual ancestors $P$. manacha and $P$. lucida (first premise). Thus, coexistent natural hybrids have distinct genotypes that might produce different phenotypes that might exhibit reduced overlap with one another and their sexual host species (second premise).

Significantly variation in reproductive investment was observed between the two natural hybrids $M L V I I$ and MLVIII but both adopted lecithotrophy. However they are distinct to their sexual host specie $P$. lucida that exhibit matrotrophy. Such difference might be another factors that facilitate the coexistence among them. Lecithotrophy might be better suited for unpredictable environment because females make a single investment when ova are yolked, then little is required to sustain the litter (Meffe and Vrijenhoek, 1981). Matrotrophic species must make a constant investment to sustain development of their litter and requires a more constant food supply than lecithotrophy (Thibault and Schultz, 1978). The metabolic advance of lecithotrophy on unstable habitats might circumvent the advantage of $P$. lucida females on sperm competition context. Males of P. lucida prefer their coespecific females reducing mating successes of coexistent natural hybrids (MLVII and MLVIII) (Lima et al., 1996). This supposition supports the second premise of the frozen nichevariation model (Vrijenhoek, 1993). The genetic diversity among laboratory made hybrids might be responsible for the large variance of the maternalembryonic relationship observed. Variation of dry weight of eggs and embryos clearly showed differences between laboratory made hybrids that belong to the same matriarchal lineage (foundresses) like the siblings strains B1 versus B2 and E1 versus E2. Differences in reproductive mode of these hybrids were bigger than differences in the sibling strains A1 versus A4.

The variation of maternal-embryonic relationship was higher among unselected laboratory made hybrids than between MLVII and MLVIII. This pattern of phenotype variation was also observed for others morphological, physiological, and behavioral traits (Wetherington et al., 1987; Wetherington et al., 1989; Lima et al., 1996; Lima and Vrijenhoek, 1996; Lima, 1998). Foundresses from Río Mayo (like E) usually produced a more diversity of hybrids' phenotypes than foudresses from Río del Fuerte (A and B).

The results of the present study confirmed that the repertory of laboratory made hybrids represented a haploid non-recombinant genome that were frozen from the genetic variation existent in foundresses 
that was fixed during hybrid formation, supporting the first premise of the frozen niche-variation model (Vrijenhoek, 1984 ; Vrijenhoek, 1993).

The reproductive characteristics expressed by hybrids did not merely reflect additive variance from the sexual ancestors species $P$. monacha and $P$. lucida. Differences among laboratory made hybrids with the same genomic dosage were highly variable. Two of them adopted different strategies observed in the natural hybrids and four laboratory made hybrids. The hybrids B1 and E2 were matrotropic and superfetater like P. lucida. The hybrids MLVII, MLVIII A1, A4, B2, and E1 were lecithotrophic and superfetater like $P$. monacha.

\section{ACKNOWLEDGMENTS}

I express my deepest gratitude to Robert C. Vrijenhoek who provided all the strains and laboratory facilities to develop this experiment during my last two years as a PhD student. I also gratefully acknowledge fellowship support from the Conselho Nacional de Pesquisa (Proc. 520798/96-1).

\section{RESUMO}

Fêmeas unissexuadas de Poeciliopsis monachalucida são biótipos híbridos que dependem do esperma da espécie parental ancestral para se reproduzir nos riachos do oeste mexicano. Os ancestrais destes híbridos são vivíparos e adotam duas estratégias reprodutivas diferentes. A espécie ancestral materna ( $P$. monacha) adota lecitotrofia, perdendo aproximadamente $25 \%$ of da massa seca dos ovos fertilizados durante a embriogênese. A espécie ancestral paterna $(P$. lucida) é matrotrofica, apresentando um pequeno acréscimo de peso durante o desenvolvimento do embrião. Fêmeas de ambas as espécies geram embriões em diferentes fases de desenvolvimento (superfetação). O objetivo do presente estudo foi analisar a relação maternoembriônica em dois híbridos naturais (fêmeas unissexuais Poeciliopsis monacha-lucida; MLVII e MLVIII) coletadas no estado de Sonora, Mexico, e num repertório de seis híbridos produzidos através de inseminação artificial (denominados como híbridos produzidos em laboratório). Peso seco de ovos maduros e embriões em três estágios de desenvolvimento diferiram significativamente entre os híbridos. Todos os híbridos à exceção dos híbridos B1 e E2 exibiram superfetação e lecitotrofia. Estes resultados mostraram que a associação entre superfetação e lecitotrofia ocorre em híbridos naturais e não está restrita à $P$. monacha.

\section{REFERENCES}

Cimino, M. C. (1972a), Meiosis in triploid allfemale fish (Poeciliopsis, Poeciliidae). Science, 175, 1484-1486.

Cimino, M. C. (1972b), Egg production, polyploidization and evolution in a diploid all-female fish of the genus Poeciliopsis. Evolution, 26, 294-306.

Constantz, G. D. (1980), Energetic of viviparity in the Gila topminnow (Pisces: Poeciliidae). Copeia, 1980, 876-878.

Leslie, J. F. (1982), Linkage analysis of seventeen loci in the poeciliid fish (genus Poeciliopsis). J. Hered., 73, 19-23.

Lima, N. R. W. (1998), Genetic analysis of predatory efficiency in natural and laboratory made hybrids of Poeciliopsis (Pisces: Poeciliidae). Behaviour, 135, 83-98.

Lima, N. R. W. and Bizerril C. R. S. F. (2002), Frequency-dependence of mating success in Poeciliopsis monacha (Pisces, Cyprinodontiformes) reproductive complex, Sonora, Mexico. Braz. Arch. Biol. Tech., 45, 161-169.

Lima, N. R. W.; Kolback, C. J. and Vrijenhoek. R. C. (1996), Evolution of sexual mimicry in spermdependent clonal forms of Poeciliopsis (Pisces: Poeciliidae). J. Evol. Biol., 9, 185-203.

Lima, N. R. W. and Vrijenhoek, R. C. (1996), Avoidance of filial cannibalism by sexual and clonal forms of Poeciliopsis (Pisces: Poeciliidae. An. Beh., 51, 293-301.

Meffe, G. K. and Vrijenhoek, R. C. (1981), Starvation stress and intraovarian cannibalism in livebearers (Atheriniformes: Peciliidae). Copeia, 1981, 702-705.

Quattro, J. M. and Weeks, S. C. (1991), Correlation of egg size and energetic content in sexual and clonal biotypes of Poeciliopsis. J. Fish Biol., 38, 331-334.

Reznick, D. N. and Mile, D. B. (1989), A review of life history patterns in poeciliid. In: Meffe, G. A. and Snelson Jr., F. F. (Eds.). Ecology and evolution of poeciliid fishes (Poeciliidae) New Jersey, USA, Prentice Hall, Englewood Cliffs. pp. 125-148.

Schenck, R. A. and Vrijenhoek, R. C. (1986), Spatial and temporal factors Affecting coexistence among sexual and clonal forms of Poeciliopsis. Evolution, 40, 1060-1070. 
Schenck, R. A. and Vrijenhoek, R. C. (1989), Coexistence among sexual and asexual forms of Poeciliopsis: Foraging behavior and microhabitat selection. In: Dawley, R. M. and Bogart, J. P. (Eds.). Evolution and ecology of unisexual vertebrate. New York State Museum Bulletin. Bulletin 466. Albany, New York, USA. pp. 39-48.

Schultz, R. J. (1967), Gynogenesis and triploidy in the viviparous fish Poeciliopsis. Science,157, 1564-1567.

Schultz, R. J. (1969), Hybridization, unisexuality and polyploidy in the teleost Poeciliopsis (Poeciliidae) and other vertebrates. Amer. Natur., 103, 605-619.

Schultz, R. J. (1982), Competition and adaptation among diploid and polyploid clones of unisexual fishes. In: Dingle, H. and Hegmann, J. P. (Eds.). Evolution and genetics of life histories. SpringerVerlag, Berlin. Germany. pp. 103-119.

Schultz, R. J. (1989) Origins and relationships of unisexual poeciliids. In: Meffe, G. A. and Snelson Jr., F. F. (Eds.). Ecology and evolution of poeciliid fishes (Poeciliidae). Prentice Hall, Englewood Cliffs, New Jersey, U.S.A. pp. 69-86.

Stenseth, N. C., Kirkendall L. R., and Moran, N. (1985), On the evolution of pseudogamy Evolution, 39, 294-307.

Thibault, R. E. and Schultz, R. J. (1978), Reproductive adaptations among viviparous fishes (Cyprinodontiformes: Poeciliidae). Evolution, 32, 320-333.

Turner, C. L. (1937), Reproductive cycle and superfetation in poeciliid fishes. Biol. Bull., 72, 145-164.

Vrijenhoek., R. C. (1978), Coexistence of clones n a heterogeneous environmental. Science, 199, 549-552.

Vrijenhoek., R. C. (1979), Factors affecting clonal diversity and coexistence. Am. Zool., 19, 787-797.

Vrijenhoek., R. C. (1984), The evolution of clonal diversity in Poeciliopsis. In: Turner, B. J. (Ed.). Evolutionary genetics of fishes. Plenum Press, New York. pp. 399-429.

Vrijenhoek., R. C. (1993), The origin and evolution of clones versus the maintenance of sex in Poeciliopsis. J. J. Hered., 84, 388-395.

Vrijenhoek, R. C.; Dawley, R. M.; Cole, C. J. and Bogart, J. P. (1989), A list of known unisexual vertebrates. In: Dawley, R. M. and Bogart, J. P. (Eds.). Evolution and ecology of unisexual vertebrates. New York State Museum Bulletin. Bulletin 466. Albany, New York, USA. pp. 19-23.
Weeks, S. C.; Gaggiotti, O. E.; Spindler, K. P. and Vrijenhoek, R. C. (1993), Feeding behavior in sexual and clonal strains of Poeciliopsis. Behav. Ecol. Sociobiol., 30, 1-6.

Weeks, S. C. (1996), A reevaluation of the Reed Queen model for the maintenance of sex in clonal-sexual fish complex (Poecillidae: Poeciliopsis). Can. Jour. Fish. Aqua. Sci., 53, 1157-1164.

Wetherington, J. D.; Kotora, K. E. and Vrijenhoek, R. C. (1987), A test of the spontaneous heterosis hypothesis for unisexual vertebrates. Evolution, 41, 721-723.

Wetherington, J. D.; Weeks, S. C.; Kotora, K. E. and Vrijenhoek, R. C. (1989), Genotypic and environmental components of variation in growth and reproduction of fish hybrids (Poeciliopsis: Poeciliidae). Evolution, 43, 635-645.

Worms, P. J. (1988), The maternal-embryonic relationship in viviparous fishes. In: Hoar, W. S. and Randal, D. J. (Eds.). Fish Physiology, Academic Press, Inc. New York, USA. pp. 1-134.

Received: April 28, 2003; Revised: October 21, 2003; Accepted: May 19, 2004. 